\title{
Concurso de Preferência
}

Pode se dar fora da execução, ainda que solvente e comerciante o devedor.

Francisco Morato

Suposto, em regra, não se dê concurso de preferência senão quando os bens do devedor não bastam para pagamento integral de todos os credores, casos há, todavia, em que o incidente pode ocorrer sem a insolvência do devedor como quando a disputa de prelação versa sôbre certos bens ou seu produto, relativamente aos quais os concorrentes têm hipoteca ou algum privilégio especial (LeIte Velho: Execuções, art. 444 e not. I - CoELHO DA RocHA: Direito Civil, § 654. - Cód. do Processo Port., art. 933).

Embora a preferência geralmente se dispute na execução dos julgados, pode acontecer que ela venha a ponto em outras circunstâncias.

Determinado por insolvência do devedor ou por privilégio atinente a bens determinados do seu patrimônio, o concurso de preferência pode verificar-se na execução ou fora da execução, em vários casos.

O concurso não é e nunca foi incidente exclusivo das execuções de sentenças. Se as nossas leis processuais dêle cogitam sob tal aspecto, a razão é que essas leis têm cuidado particularmente das execuções e que nas execuções é que comumente se levanta o incidente. 
E' um fenômeno que se manifesta pela circunstância de preferência de algum ou alguns credores sôbre os bens ou sôbre o produto dos bens do devedor comum; o que visivelmente pode acontecer, tanto nas execucões como em outras hipóteses.

E' o que está nas tradições do nosso direito e na lição de Silva, Solon, Lobão, Ribas e outros práticos.

Clovis Bevilaqua (Cód. Civ. Com., V obs. ao art. 1.554) refere-se expressamente ao concurso de credores nos inventários. Lobão (Execuções: $\S \S 485$ e 534) aponta nove casos dêle, entre os quais o da Ord. do L. 4 tit. 6 princíp. ıe $\S 1 .^{\circ}$, em que o adquirente de coisa sujeita a hipoteca ou privilégio recorre ao juiz para que faça depositar o preço e citar os credores do alienante, afim de debaterem seus direitos acêrca da propriledade adquirida ou da soma consignada; situação perfeitamente análoga à do expropriante que, para receber, expurgada de onus, a coisa desapropriada, provoca o concurso entre os credores do expropriado.

A lei n. 353 de 12 de junho de 1854 consagra de modo explícito a formalidade do concurso nas causas de desapropriação, prescreviendo no art. 31 que se proceda a êle tanto que seja depositado o preço, para que o objeto desapropriado se considere livre de todos os onus, hipotecas e lides pendentes.

Na sua "Consolidação das Leis do Processo Civil", Ribas, depois de sintetizar esse dispositivo no art. 1.141, salienta no art. 1.388, que o concurso de preferência não é peculiaridade das execuções de sentença.

Diz-se que estão revogados hoje, em face do novo regime da publicidade das hipotecas e do Código Civil, os preceitos da Ord. cit. e os arts. 1.141 e 1.338 da Consolidação de Rrbas, êstres últimos, aliás, de aplicação restrita às desapropriações na Côrte do Rio de Janeiro.

Pouco importa; não estão revogadas as tradições nem o sistema do direito. Os aludidos preceitos demonstram irresistivelmente a tese em debate, a saber, que, na doutrina e na prática do Direito Judiciário, o concurso de preferên- 
cia, longe de ser incidente exclusivo das execuções, é de aplicação possivel e naturalíssima nas causas de desapropriação e outras.

Mais do que isso; é de aplicação necessária. Temos lei expressa.

Há no Livro II do Código Civil um Título (é o IX) subordinado à rubrica do "concurso de credores" onde o legislador, nos arts. 1.558 n. II e 1.559, estatúi "que os créditos hipotecários ou privilegiados, no caso de desapropriação, se transmudam da coisa sujeita à hipoteca ou privilégio para a indenização devida e que o desapropriante se libera do onus, pagando-a sem oposição dos credores hipotecários ou privilegiados"

Aí está o concurso no processo de desapropriação, prescrito de modo inequívoco, como resulta das mesmas palavras da epígrafe do Título IX e do teor dos referidos artigos; porque, si os credores não anuem a que a indenização se pague ao expropriado, o único remédio que tem o expropriante é depositar o preço, não à disposição do expropriado, como inadvertidamente se tem sustentado, mas à disposição dos credores, como dispõe o art. $762 \mathrm{n}$. V do mesmo Cód. Civil, afim de que sôbre êle disputem e liquidem seus direitos.

Julgou-se de modo contrário a êste ponto de vista no processo de desapropriação da S. Paulo Northern Railroad Company. Opinou aí Es'revam de Almeida, acompanhado de Pinto Ferraz, Clovis Bevilaqua, Eduardo Spinola, Paulo de Lacerda, Bento de Faria, Astolpho Rezende, Lacerda de Almeida e Martinho Garcez, que o processo de desapropriação decorre entre o expropriante e o proprietário, sendo a êle estranhos os credores do expropriado; que é uma aberração o concurso de preferência em tal processo; que o concurso é incidente da execução; que o único meio de concorrerem os credores ao preço depositado, seria um dêles penhorar o dinheiro e instaurar-se o concurso, vindo os outros com seu protesto. 
Foi, segundo parece, um equívoco de grandes mestres, como salientamos acima.

Não colhia dizer que se poderia evitar o embaraço, promovendo um credor a penhora da soma da indenização $\mathrm{e}$ concorrendo os outros a êsse feito com seu protesto.

Em primeiro lugar, não havia embaraço nenhum a evadir. O concurso não é peculiaridade da execução; é também incidente da desapropriação.

Em segundo, seria um torneio sem sentido, sem alcance, ditado por abissinismo de forma, insustentável perante os princípios filosóficos da processualística. Para que o rodeio, quando desde logo se poderia abrir a instância do concurso de preferência, sem essa formalidade, que nada adianta, nem para as partes nem para a realização ou vida do direito?

Não colheria tão pouco argumentar que não temos lei geral regulando o processo do concurso nas causas de desapropriação.

Temos. E' o próprio reg. 737 de 1850 ou o dec. n. 355 de 1845 , qualquer dos quais pode e deve ser aplicado como legislação subsidiária, em falta de regulamento específico.

Quando não tivéssemos, devia a justiça recorrer aos princípios gerais de direito judiciário, segundo a doutrina e exemplos dos autores e dos códigos, para na conformidade dêles formular um processo adequado à hipótese. Sacrificar o direito substantivo por falta de direito adjetivo, seria um contrasenso.

A aplicação, nos casos omissos, das disposições concernentes aos casos análogos, e, não as havendo, dos principios gerais de direito, é uma regra que domina o quadro integral da jurisprudência.

O princípio da analogia, que rege o direito material, é o mesmo que governa o direito processual. Conforme adverte ChIovenda, embora a aplicação analógica se haja de fazer em casos excecionais e com suma cautela, o certo é que a ela se recorre freqüentemente no campo da processualística (Principii di Diritto Processuale Civile, Part. I, § 4, n. VI). 
Vários dos Códigos de Processo dos Estados permitem o concurso nas desapropriações e em muitas hipóteses estranhas à execução.

Haja vista o de Minas Gerais, no art. 1.276 n. 2. Haja vista o de S. Paulo, no art. 97, onde o admite nos inventários, arrolamentos, arrecadações e dissoluções de sociedade; e no art. 643, onde permite ingresso no processo expropriatório ao locatário, comodatário, credor com garantia real e, em geral, a todos aqueles cujos direitos hajam de ficar sub-rogados na indenização.

O Reg. 737 de 1850 trata do concurso de preferência como incidente da execução, submetendo-o a três cláusulas: a) não ter o devedor comum bens suficientes para o pagamento de todos os credores; $b$ ) não ser comerciante o devedor; $c$ ) virem os credores a juizo, antes de entregue ao exeqüente o preço da arrematação ou de extraída e assinada a carta de adjudicação (art. 609).

Disciplinando o instituto sob êste ponto de vista limitado, estranho aos casos em que a disputa se possa travar fora das execuções de sentença, não cogitou o regulamento comercial do concurso nas desapropriações, hipótese à qual suas regras não se aplicam nem se poderiam aplicar, senão por analogia, para reger a forma, disposição e movimento do processo.

Incivil seria, portanto, querer vedar o concurso de preferência em desapropriação em que o desapropriado fôsse comerciante, simplesmente por não permitir o Reg. 737 tal incidente contra "executado comerciante".

Aliás, nada tem uma coisa com outra; o expropriado não é um executado. Na expropriação, o concurso recái sòmente sôbre a coisa expropriada, não abrange o patrimônio integral do proprietário devedor nem pressupõe a insolvência dêste. 
A razão do dispositivo do art. $609 \S 20^{\circ}$ do Reg. 737 é de facil entendimento. Entende-se falido o comerciante que, executado, mesmo por dívida civil, não paga a importância da condenação ou não segura o juizo para poder embargar. Falido o comerciante, fica aberto entre os credores o concurso sôbre a universalidade dos bens do devedor, que tal é, em fórma solene, o processo de falência; dispensando-se, por conseguinte, a instância de preferência incidente nas execuções. 